\title{
SISTEM INFORMASI MANAJEMEN ARSIP ELEKTRONIK (E-ARSIP) BERBASIS WEB PADA MARCOM BSI GROUP
}

\author{
M. Iqbal Alifudin[1]; Susy Rosyida ${ }^{[2]}$
}

Fakultas Teknik Informatika [1][2]

Universitas Nusa Mandiri

iqbal.alifudin@gmail.com[1], susyrosyida@gmail.com ${ }^{[2]}$

\begin{tabular}{ll}
\hline INFO ARTIKEL & INTISARI \\
\hline Diajukan : & Yayasan Bina Sarana Informatika (BSI) memiliki divisi bagian Marketing \\
11 Juli 2021 & and Communication (Marcom) yang bertujuan untuk memperkenalkan dan \\
& menanamkan citra produk pendidikan perguruan tinggi Universitas Bina \\
Diterima : & Sarana Informatika kepada masyarakat. Marcom BSI memiliki lebih dari 50 \\
08 Agustus 2021 & karyawan yang dapat mengirimkan permintaan barang untuk menunjang \\
Diterbitkan: & tujuan tersebut. Proses pengarsipan data barang pada Marcom BSI masih \\
01 Desember 2021 & menggunakan Microsoft Excel yang dikelola oleh administrasi. Hal ini \\
& membuat data karyawan menjadi usang karena hanya administrasi yang \\
Kata Kunci : & dapat mengubah data dan riwayat keluar masuk barang juga tidak tercatat \\
Laravel, Pengarsipan, PHP, & dengan baik karena hanya data akhir saja yang dapat tersimpan. Sistem \\
Waterfall, Web, & informasi yang dapat memudahkan Marcom BSI yaitu dengan memiliki \\
& sistem yang dapat mengelola pengarsipan data data barang. Teknik \\
& pengumpulan data dilakukan dengan cara observasi, wawancara, dan studi \\
& pustaka. Metode waterfall dipilih sebagai model pengembangan perangkat \\
& lunak, sedangkan untuk perancangannya menggunakan UML (Unified \\
& Modelling Language), ERD (Entity Relationship Diagram). Sistem informasi \\
& dibuat menggunakan bahasa pemrograman PHP dengan framework \\
& Laravel yang menghasilkan sebuah web pengarsipan data barang pada \\
& Marcom BSI.
\end{tabular}

\section{PENDAHULUAN}

Teknologi sudah menjadi bagian dari perkembangan kehidupan manusia dan hampir semua kegiatan manusia mengikut sertakan peranan teknologi. Teknologi informasi merupakan salah satu dari sekian jenis teknologi yang berperan penting dalam kegiatan manusia. Teknologi informasi secara umum diartikan sebagai sistem berbasis komputer yang terdiri dari perangkat keras (hardware) dan perangkat lunak (software) (Karisman, 2019) yang dipergunakan sebagai tempat menyimpan, memproses dan mengirim informasi kepada orang lain secara cepat dan mudah. Selain teknologi informasi, terdapat juga sistem informasi yang merupakan gabungan dari teknologi informasi dengan aktivitas manusia yang memakai teknologi untuk mendukung (Widiati et al., 2015) kegiatan manajemen dan operasional yang dilakukan oleh suatu instansi atau lembaga supaya kegiatan yang dilakukan dapat berjalan dengan efisien, terstruktur dan efektif.

Sistem informasi memberikan dampak terhadap kehidupan sehari-hari salah satunya pengaksesan informasi yang sangat mudah dan cepat melalui sebuah web. Sistem informasi berbasis web dapat diakses secara bersama-sama dengan mudah, kapan saja dan dari mana saja tidak perlu bergantung pada komputer lokal atau kantor dan bisa mendukung proses bisnis yang berjalan pada sebuah kantor karena fleksibilitasnya (Ariesandika, Wicaksono, \& Pradana, 2018).

Arsip merupakan rekaman catatan dokumen atau sumber informasi berupa surat ataupun proposal yang berfungsi sebagai proses kegiatan manajemen atau aktivitas suatu instansi. Arsip bisa berguna secara maksimal untuk instansi apabila dapat dikelola dengan baik, akan tetapi sebaliknya arsip akan menyebabkan permasalahan untuk instansi apabila tidak dikelola dengan baik (Purba, Martono, \& Sukma, 2018). Berdasarkan masalahnya, jenis arsip dibagi menjadi 5, yaitu financial record, inventory record, personal record, sales record, dan production record (Riasmiati, 2016). Pada penelitian ini, hal yang dibahas yaitu mengenai inventory record atau pengelolaan barang inventaris dan personal record atau arsip data kepegawaian.

Yayasan Bina Sarana Informatika (BSI) memiliki divisi bagian Marketing and Communication (Marcom). Pengarsipan data Sumber Daya Manusia (SDM) meliputi data 
karyawan yang bekerja pada Marcom BSI mencapai sekitar 50 orang dan dibagi ke dalam beberapa tim atau unit. Administrasi bertugas mengelola data SDM (Sumber Daya Manusia) yang meliputi data karyawan Marcom BSI, mengelola barang seperti brosur, jam dinding, mug dan lainlain. Karyawan dapat mengirimkan permintaan barang untuk menunjang tujuan Marcom BSI dalam memperkenalkan dan menanamkan citra produk pendidikan perguruan tinggi Universitas Bina Sarana Informatika kepada masyarakat.

Saat ini, pengarsipan data barang dan pengelolaan data SDM Marcom BSI masih menggunakan Microsoft Excel yang mengakibatkan data hanya dapat diakses melalui komputer kantor atau komputer yang memiliki duplikat dokumen tersebut. Proses pencarian data juga terkendala karena dokumen data dicari dengan cara manual. Jika ada perubahan data karyawan, administrasi yang harus mencari dan mengubah data yang bersangkutan. Selain itu, karena hanya administrasi saja yang menyimpan data pengarsipan, transparansi data barang menjadi kurang, ketika tim lain membutuhkan data ketersediaan barang maka harus menanyakan ke administrasi terlebih dahulu.

Oleh sebab itu, Marcom BSI perlu memiliki sistem yang dapat memudahkan untuk mengelola pengarsipan sehingga prosesnya berjalan dengan efektif, cepat dan aman. Hal inilah yang melatarbelakangi penelitian untuk merancang sistem informasi pengarsipan secara elektronik berbasis web yang nantinya dapat digunakan sebagai alat bantu dalam pengarsipan dan pengelolaan laporan pada Marcom BSI.

\section{BAHAN DAN METODE}

Langkah penting dalam penelitian untuk merancang sistem yaitu pengumpulan data. Pengumpulan data dilakukan melalui:

1. Observasi

Mengamati secara langsung pada administrasi Marcom BSI yang berkaitan dengan pengarsipan data barang.

2. Wawancara

Tanya jawab untuk mendapatkan data yang dibutuhkan kepada administrasi serta karyawan lain yang membutuhkan sistem informasi pengarsipan ini.

3. Studi Pustaka

Studi kepustakaan tentang permasalahan yang dibahas serta untuk memperoleh landasan teori dari sistem informasi yang akan dibuat melalui referensi atau literatur-literatur, baik itu di buku maupun di internet.

Pada sistem informasi e-arsip, model pengembangan sistem yang digunakan model waterfall (air terjun). Pelaksanaan metode waterfall dilakukan secara bertahap dan terinci dengan menggunakan pendekatan sekuensial untuk pengembangan sistem informasi (Pressman \& Maxim, 2019). Penggunaan metode waterfall mempunyai tahapan-tahapan antara lain:

1. Analisa Kebutuhan

Mengamati setiap masalah yang ada pada administrasi Marcom BSI khususnya pada pencatatan barang dan data SDM Marcom BSI. Mengidentifikasi permasalahan dan mendeskripsikan sistem yang sudah berjalan kemudian merekomendasikan perbaikan untuk meningkatkan sistemnya dengan membuat pengarsipan elektronik berbasis web sehingga sistem informasi yang diterapkan dapat berjalan dengan efisien dan efektif.

2. Desain

Pada tahap ini pemodelan sistem terbagi menjadi 3 (tiga) antara lain:

a. Pemodelan sistem menggunakan diagram UML. Dengan behavioral diagram yaitu use case diagram, activity diagram, sequence diagram. Sedangkan structural diagram terdiri dari class diagram, component diagram, deployment diagram,

b. Pemodelan database MySQL dibuat dengan menggunakan entity relationship diagram (ERD).

\section{Code Generation}

Sistem yang sudah dianalisis serta dirancang mulai dibangun dengan menerjemahkannya kedalam bahasa pemrograman. Menggunakan bahasa pemrograman PHP dan dibantu dengan framework Laravel mengikuti alur sistem yang sudah dirancang dan yang sudah berjalan sebelumnya kemudian mengubahnya menjadi sistem informasi berbasis web.

4. Testing

Pengujian dilakukan untuk memeriksa program yang dibuat serta memastikan bahwa fungsi dan logika program serta hasil atau output yang diperoleh memenuhi kebutuhan pengguna.

5. Support

Pada tahap pemeliharaan, hal yang perlu diperhatikan di antaranya user harus dapat menjalankan sistem dengan lancar tanpa terkendala.

\section{HASIL DAN PEMBAHASAN}

\section{Analisa Kebutuhan}

Berdasarkan data yang diperoleh dari Marcom BSI, disimpulkan bahwa analisa kebutuhan meliputi:

a. Semua pengguna dapat login

b. Semua pengguna dapat melihat data item 
c. Karyawan dapat meminta barang

d. Karyawan bisa mendapatkan umpan balik atas permintaan barang

e. Kepala Divisi dapat memberikan persetujuan permintaan barang

f. Kepala Divisi dapat melihat riwayat permintaan barang

g. Administrasi dapat membuat akun karyawan

h. Administrasi dapat melihat catatan riwayat permintaan item

2. Desain

Pada tahap design yang akan dibahas yaitu pemodelan sistem, database.

a. Use Case Diagram

Menggunakan use case diagram untuk mengetahui fungsi yang terdapat pada suatu sistem informasi arsip elektronik serta menetapkan aktor yang berwenang untuk memakai fungsi-fungsi tersebut.

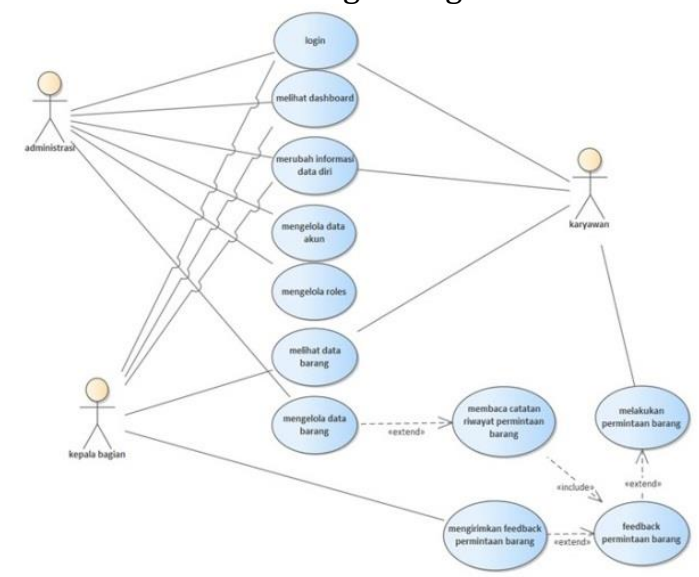

Sumber: Hasil Penelitian (2021)

Gambar 1. Use Case Diagram

b. Activity Diagram

Activity diagram untuk mengetahui urutan aktivitas suatu proses pada suatu sistem informasi arsip elektronik dan aktor yang terlibat pada aktivitas tersebut.

Terdapat dua aktor yaitu interaksi administrasi (user) dalam mengelola data barang dengan sistem e-arsip. Pada aktivitas ini user dapat menampilkan daftar data barang, menambah, mengedit, menghapus dan mencetak data barang, selain itu juga dapat melihat catatan riwayat permintaan barang.

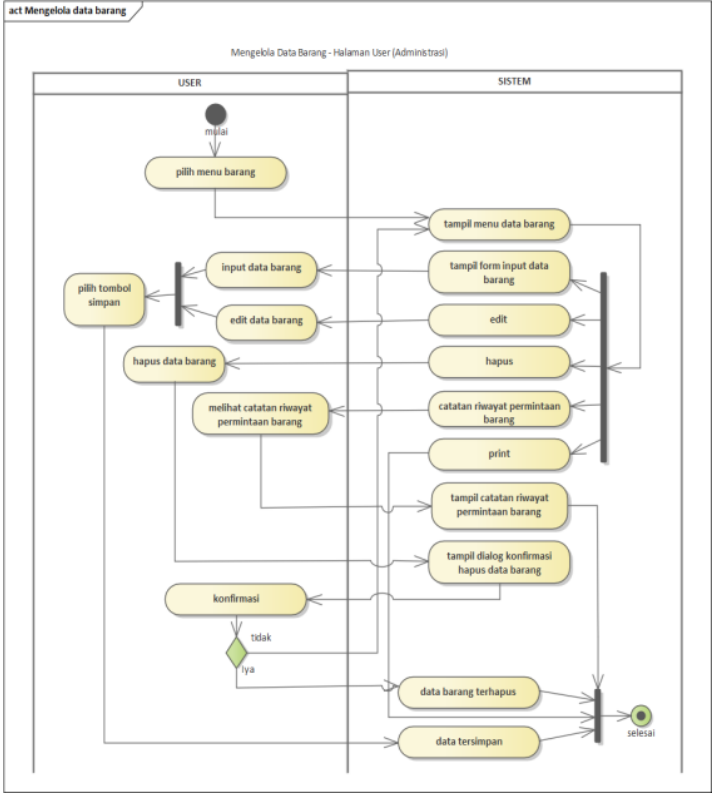

Sumber: Hasil Penelitian (2021)

Gambar 2. Activity Diagram Mengelola Data Barang

User harus mengecek ketersediaan data barang sebelum melakukan permintaan, untuk melakukan permintaan barang harus melalui menu permintaan data barang dan mengisi form data permintaan.

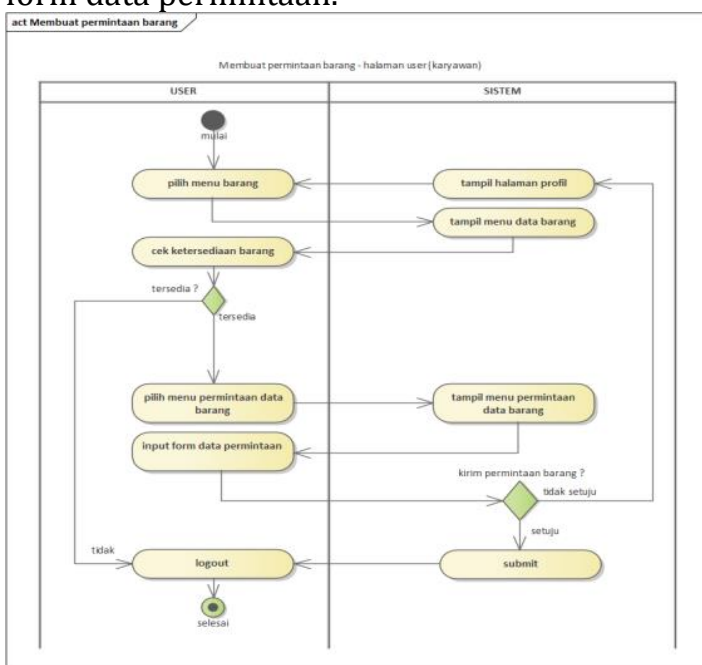

Sumber: Hasil Penelitian (2021)

Gambar 3. Activity diagram membuat permintaan barang

User dapat menampilkan daftar permintaan barang melalui menu permintaan barang, kemudian mengirimkan persetujuan permintaan yang belum terselesaikan. 


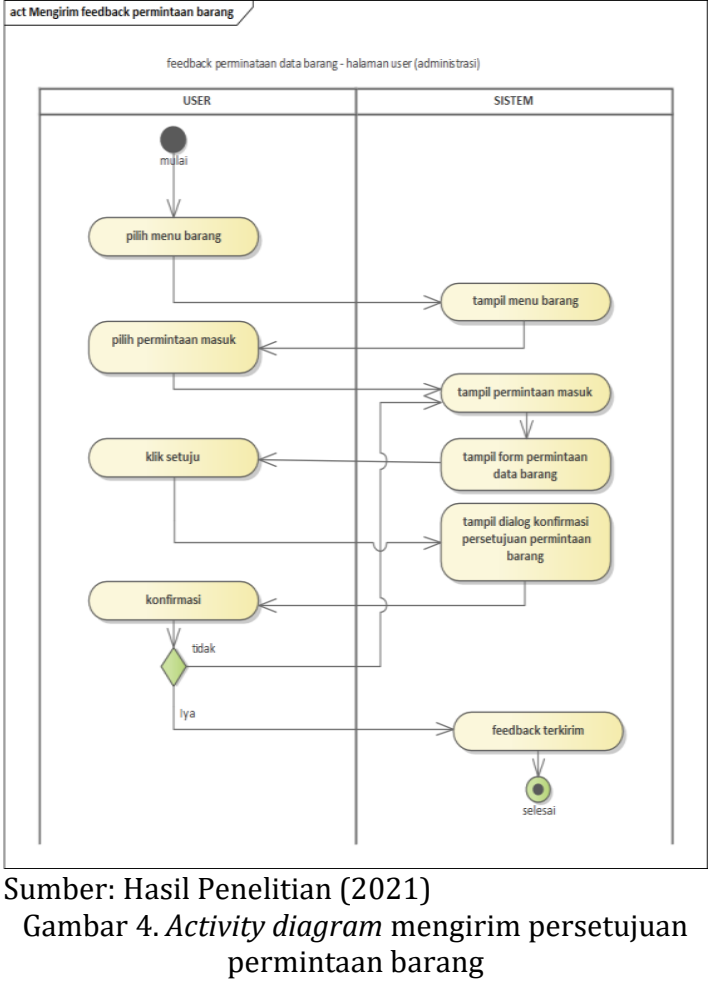

Database digunakan untuk merancang hubungan antar tabel yang dibuat berserta relasi antar tabel. Pada pembuatan sistem informasi e-arsip ini database dibuat menggunakan Entity Relationship Diagram (ERD).

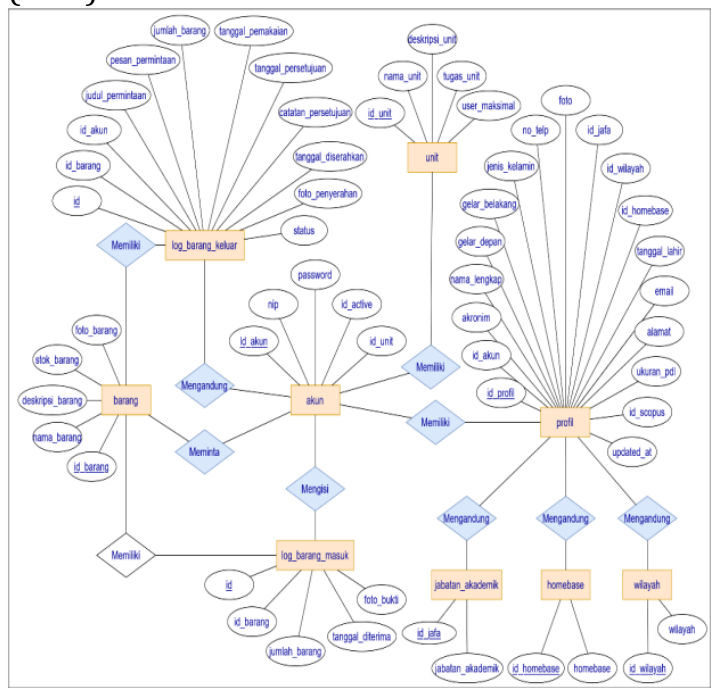

Sumber: Hasil Penelitian (2021)

Gambar 5. Entity relationship diagram

Class diagram yang menunjukkan perilaku dan hubungan antar class satu dengan yang lainnya, memiliki informasi tentang fitur dari entitas maupun penggunanya. Pada sistem earsip ini terdapat 9 class yang memiliki hubungan satu sama lain. Berikut gambar dari class diagram tersebut:

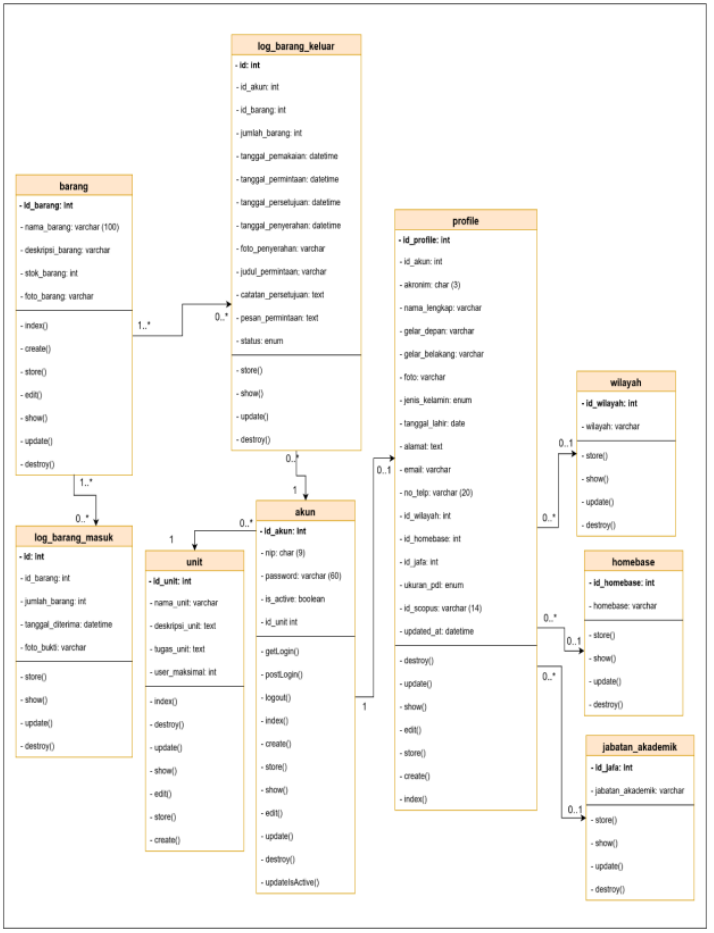

Sumber: Hasil Penelitian (2021)

Gambar 6. Class diagram

Sequence diagram mengelola data barang terdapat beberapa fungsi pada menu barang yaitu menambah data barang, mengedit data barang, menghapus data barang, dan melihat catatan riwayat permintaan barang. Semua hal yang dilakukan user/actor disimpan ke dalam tabel barang.myd pada database.

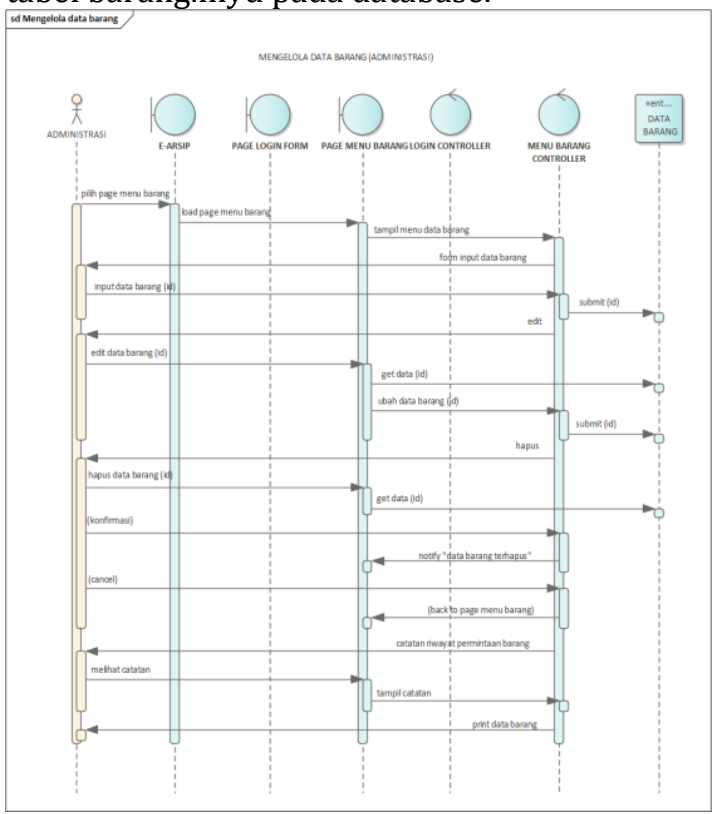

Sumber: Hasil Penelitian (2021)

Gambar 7. Sequence diagram mengelola data barang Sequence diagram membuat permintaan barang melalui menu permintaan data barang yang ada di dalam menu barang, input form data permintaan barang sesuai kebutuhan lalu 
klik submit untuk menyimpan data permintaan barang.

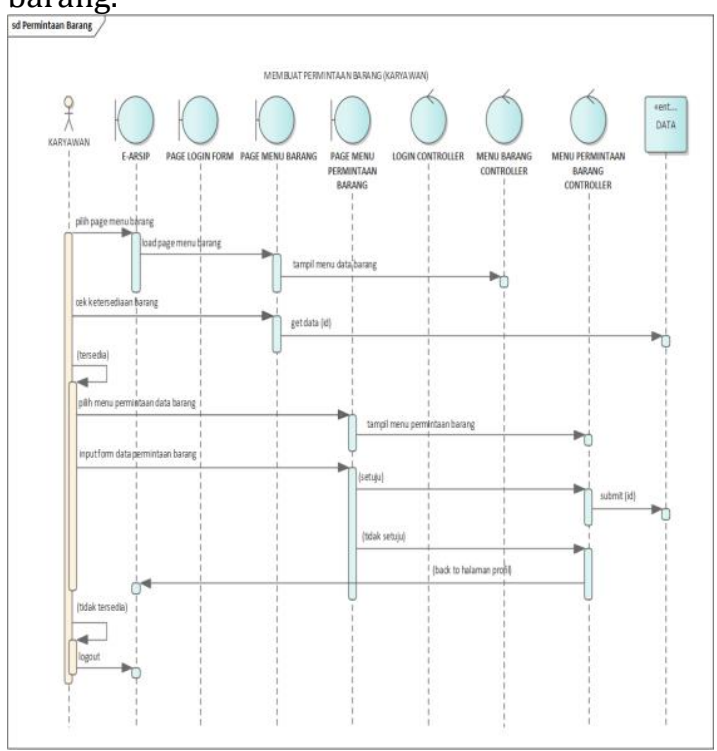

Sumber: Hasil Penelitian (2021)

Gambar 8. Sequence diagram membuat permintaan barang

Component diagram digunakan untuk menampilkan komponen-komponen yang ada pada sistem dan hubungan atau interaksi yang terjadi didalam sistem.

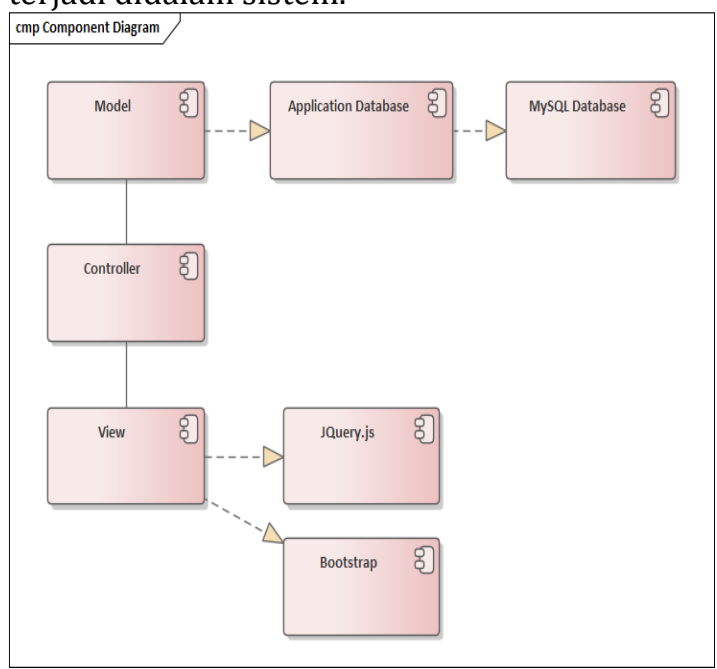

Sumber: Hasil Penelitian (2021)

Gambar 9. Component Diagram

Deployment diagram digunakan untuk mewakili penyebaran sistem sehingga satu sistem memiliki satu deployment diagram. Deployment diagram memiliki sebuah node, setiap node mewakilkan salah satu bagian dari perangkat keras (hardware). Bentuk dari deployment diagram, seperti dibawah ini:

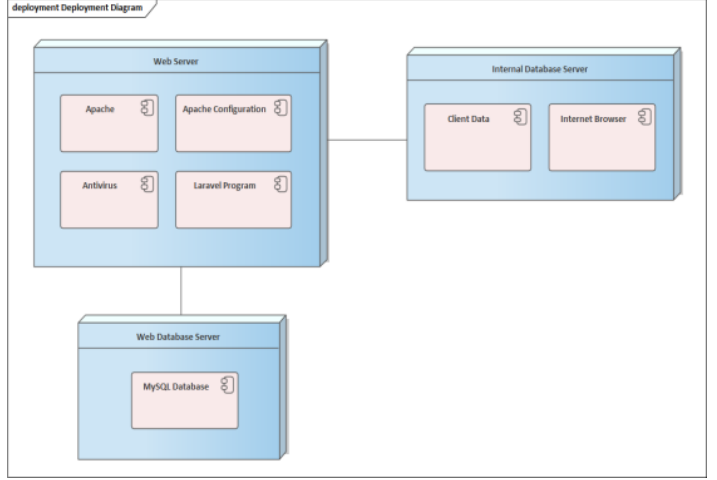

Sumber: Hasil Penelitian (2021)

Gambar 10. Deployment diagram

\section{Code Generation}

Laravel 8 memiliki 2 opsi untuk menangani masalah autentikasi, yaitu menggunakan starter kit aplikasi dan autentikasi manual.

Seluruh User diharuskan untuk mengisi halaman login sebelum bisa menggunakan sistem. Form login terdiri dari NIP dan Password yang akan dicocokkan datanya yang tersedia pada table akun.myd.

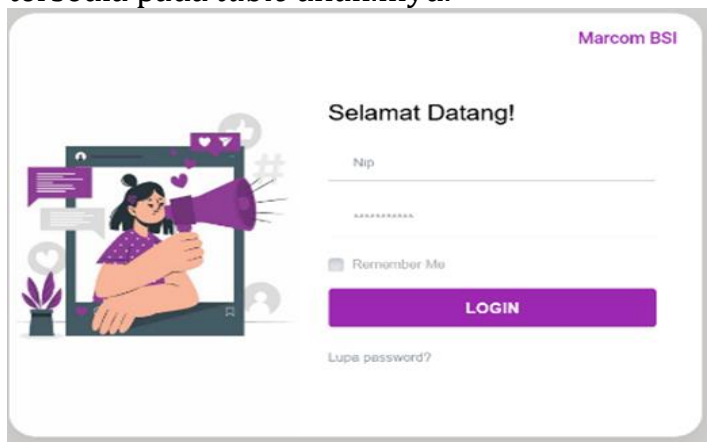

Sumber: Hasil Penelitian (2021)

Gambar 11. Tampilan halaman form login

Halaman ini digunakan administrasi untuk menambahkan data barang dan memasukkan data barang baru. Sebelum memasuki form ini, akan muncul form berbentuk modal yang digunakan untuk menentukan banyak input data barang yang akan diisi melalui form ini.

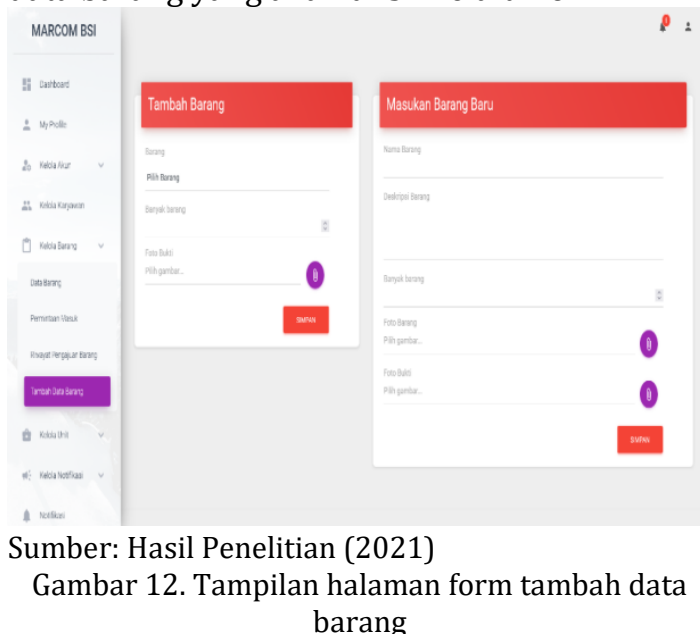


Halaman ini digunakan karyawan untuk membuat pengajuan permintaan barang yang akan dikirimkan kepada user kepala bagian. Sama seperti halaman tambah data barang, akan muncul form berbentuk modal yang digunakan untuk menentukan banyak input data barang yang akan diisi melalui form ini.

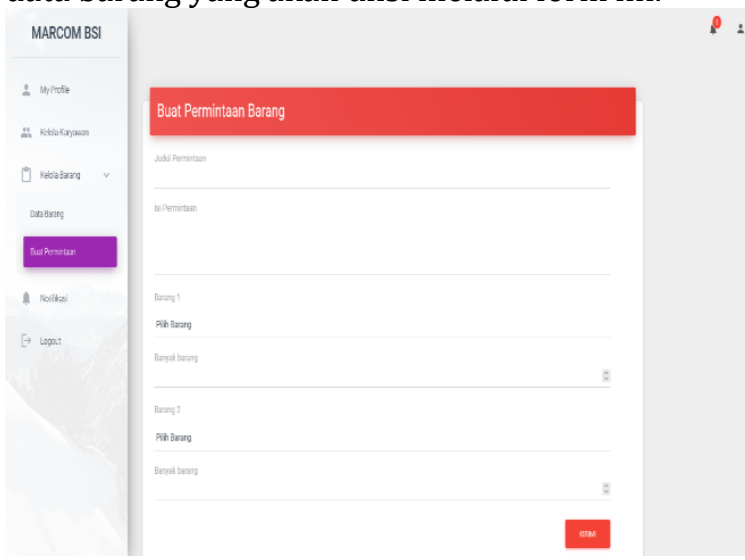

Sumber: Hasil Penelitian (2021)

Gambar 13. Tampilan halaman form pengajuan barang

Halaman form ini digunakan kepala bagian untuk melakukan respons terhadap persetujuan barang yang telah dikirimkan oleh karyawan, apakah pengajuannya disetujui ataupun ditolak.

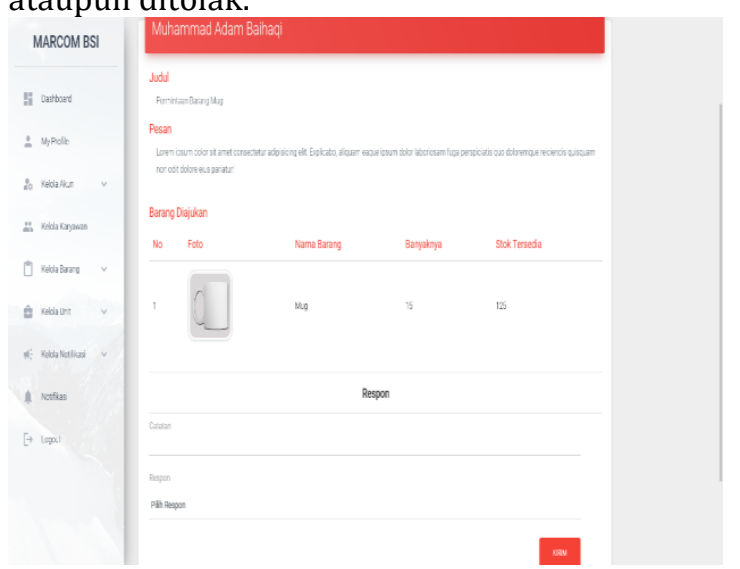

Sumber: Hasil Penelitian (2021)

Gambar 14. Tampilan halaman form persetujuan barang

4. Testing

Untuk melakukan testing sistem informasi earsip, menggunakan teknik black box yaitu dengan cara mencoba langsung sistem yang telah selesai dibuat untuk mencari error atau bug sehingga menghasilkan informasi yang akurat.

Tabel 1.

Hasil pengujian black box testing form input barang

\begin{tabular}{|c|c|c|c|c|c|}
\hline $\mathbf{N}$ & $\begin{array}{c}\text { Skena } \\
\text { rio } \\
\text { o } \\
\text { Pengaj } \\
\text { uan }\end{array}$ & $\begin{array}{c}\text { Test } \\
\text { Case }\end{array}$ & $\begin{array}{c}\text { Hasil Yang } \\
\text { Diharapka } \\
\mathbf{n}\end{array}$ & $\begin{array}{c}\text { Hasil } \\
\text { Pengu } \\
\text { jian }\end{array}$ & $\begin{array}{c}\text { Kesi } \\
\text { mpu } \\
\text { lan }\end{array}$ \\
\hline 1 & Mengo & Nama & Sistem & Sesuai & Valid \\
\hline
\end{tabular}

\begin{tabular}{|c|c|c|c|c|c|}
\hline & $\begin{array}{l}\text { songka } \\
\mathrm{n} \\
\text { semua } \\
\text { form } \\
\text { input } \\
\text { barang } \\
\text { kemud } \\
\text { ian } \\
\text { klik } \\
\text { tombol } \\
\text { simpa } \\
\text { n }\end{array}$ & $\begin{array}{l}\text { Barang: } \\
\text { (kosong) } \\
\text { Deskrips } \\
\text { i Barang: } \\
\text { (kosong) } \\
\text { Stok: } \\
\text { (kosong) } \\
\text { Foto } \\
\text { Barang: } \\
\text { (kosong) }\end{array}$ & $\begin{array}{l}\text { akan } \\
\text { menolak } \\
\text { dan } \\
\text { menampilk } \\
\text { an form } \\
\text { input data } \\
\text { barang } \\
\text { kosong, } \\
\text { silakan } \\
\text { input } \\
\text { kembali }\end{array}$ & $\begin{array}{l}\text { harapa } \\
n\end{array}$ & \\
\hline 2 & $\begin{array}{l}\text { Hanya } \\
\text { mengis } \\
\text { i salah } \\
\text { satu } \\
\text { form } \\
\text { input } \\
\text { barang } \\
\text {, lalu } \\
\text { klik } \\
\text { tombol } \\
\text { simpa } \\
\text { n }\end{array}$ & $\begin{array}{l}\text { Nama } \\
\text { Barang: } \\
\text { (kosong) } \\
\text { Deskrips } \\
\text { i Barang: } \\
\text { (kosong) } \\
\text { Stok: } \\
\text { (kosong) } \\
\text { Foto } \\
\text { Barang: } \\
\text { (kosong) }\end{array}$ & $\begin{array}{l}\text { Sistem } \\
\text { akan } \\
\text { menolak } \\
\text { dan } \\
\text { menampilk } \\
\text { an form } \\
\text { input } \\
\text { barang } \\
\text { belum } \\
\text { lengkap, } \\
\text { silakan } \\
\text { input } \\
\text { kembali }\end{array}$ & $\begin{array}{l}\text { Sesuai } \\
\text { harapa } \\
n\end{array}$ & Valid \\
\hline 3 & $\begin{array}{l}\text { Mengi } \\
\text { nputka } \\
\text { n data } \\
\text { barang } \\
\text { denga } \\
\mathrm{n} \\
\text { benar } \\
\text { kemud } \\
\text { ian } \\
\text { klik } \\
\text { tombol } \\
\text { simpa } \\
\text { n }\end{array}$ & $\begin{array}{l}\text { Nama } \\
\text { Barang: } \\
\text { Mug } \\
\text { Deskrips } \\
\text { i Barang: } \\
\text { terdapat } \\
\text { logo } \\
\text { UBSI } \\
\text { Stok: } 50 \\
\text { Foto } \\
\text { Barang: } \\
\text { mug.jpg }\end{array}$ & $\begin{array}{l}\text { Sistem } \\
\text { akan } \\
\text { menampilk } \\
\text { an daftar } \\
\text { data } \\
\text { barang } \\
\text { yang sudah } \\
\text { terinput } \\
\text { dan } \\
\text { muncul } \\
\text { alert data } \\
\text { barang } \\
\text { berhasil } \\
\text { tersimpan }\end{array}$ & $\begin{array}{l}\text { Sesuai } \\
\text { harapa } \\
n\end{array}$ & Valid \\
\hline
\end{tabular}

Sumber: Hasil Penelitian (2021)

Tabel 2.

Hasil pengujian black box testing form Input

\begin{tabular}{|c|c|c|c|c|c|}
\hline \multicolumn{6}{|c|}{ permintaan barang } \\
\hline $\begin{array}{l}\mathbf{N} \\
\mathbf{0}\end{array}$ & $\begin{array}{c}\text { Skena } \\
\text { rio } \\
\text { Penga } \\
\text { juan }\end{array}$ & Test Case & $\begin{array}{c}\text { Hasil Yang } \\
\text { Diharapk } \\
\text { an }\end{array}$ & $\begin{array}{c}\text { Hasi } \\
1 \\
\text { Pen } \\
\text { guji } \\
\text { an }\end{array}$ & $\begin{array}{c}\text { Ke } \\
\text { si } \\
\text { m } \\
\text { pu } \\
\text { la } \\
\text { n }\end{array}$ \\
\hline 1 & $\begin{array}{l}\text { Mengo } \\
\text { songka } \\
\mathrm{n} \\
\text { semua } \\
\text { form } \\
\text { input } \\
\text { permi } \\
\text { ntaan } \\
\text { barang } \\
\text { kemud } \\
\text { ian } \\
\text { klik } \\
\text { tombol } \\
\text { simpa } \\
\mathrm{n}\end{array}$ & $\begin{array}{l}\text { Nama } \\
\text { Barang: } \\
\text { (kosong) } \\
\text { Jumlah } \\
\text { barang: } \\
\text { (kosong) } \\
\text { Tanggal } \\
\text { Permintaan: } \\
\text { (kosong) } \\
\text { Pesan } \\
\text { Permintaan: } \\
\text { (kosong) } \\
\text { Status: } \\
\text { (kosong) }\end{array}$ & $\begin{array}{l}\text { Sistem } \\
\text { akan } \\
\text { menolak } \\
\text { dan } \\
\text { menampilk } \\
\text { an form } \\
\text { input } \\
\text { permintaa } \\
\text { n barang } \\
\text { kosong, } \\
\text { silakan } \\
\text { input } \\
\text { kembali }\end{array}$ & $\begin{array}{l}\text { Sesu } \\
\text { ai } \\
\text { hara } \\
\text { pan }\end{array}$ & $\begin{array}{l}\text { Va } \\
\text { lid }\end{array}$ \\
\hline 2 & $\begin{array}{l}\text { Hanya } \\
\text { mengis } \\
\text { i salah } \\
\text { satu } \\
\text { form } \\
\text { input }\end{array}$ & $\begin{array}{l}\text { Nama } \\
\text { Barang: mug } \\
\text { Jumlah } \\
\text { barang: } \\
\text { (kosong) } \\
\text { Tanggal }\end{array}$ & $\begin{array}{l}\text { Sistem } \\
\text { akan } \\
\text { menolak } \\
\text { dan } \\
\text { menampilk } \\
\text { an form }\end{array}$ & $\begin{array}{l}\text { Sesu } \\
\text { ai } \\
\text { hara } \\
\text { pan }\end{array}$ & $\begin{array}{l}\mathrm{Va} \\
\text { lid }\end{array}$ \\
\hline
\end{tabular}




\begin{tabular}{|c|c|c|c|c|c|}
\hline & $\begin{array}{l}\text { permi } \\
\text { ntaan } \\
\text { barang } \\
\text {, lalu } \\
\text { klik } \\
\text { tombol } \\
\text { simpa } \\
\text { n }\end{array}$ & $\begin{array}{l}\text { Permintaan: } \\
\text { (kosong) } \\
\text { Pesan } \\
\text { Permintaan: } \\
\text { (kosong) } \\
\text { Status: } \\
\text { (kosong) }\end{array}$ & $\begin{array}{l}\text { input } \\
\text { permintaa } \\
\text { n barang } \\
\text { belum } \\
\text { lengkap, } \\
\text { silakan } \\
\text { input } \\
\text { kembali }\end{array}$ & & \\
\hline 3 & $\begin{array}{l}\text { Mengi } \\
\text { nputka } \\
\text { n } \\
\text { permi } \\
\text { ntaan } \\
\text { barang } \\
\text { denga } \\
\text { n } \\
\text { benar } \\
\text { kemud } \\
\text { ian } \\
\text { klik } \\
\text { tombol } \\
\text { simpa } \\
\text { n }\end{array}$ & $\begin{array}{l}\text { Nama } \\
\text { Barang: mug } \\
\text { Jumlah } \\
\text { barang: } 20 \\
\text { Tanggal } \\
\text { Permintaan: } \\
\text { 22 Juli } 2021 \\
\text { Pesan } \\
\text { Permintaan: } \\
\text { sebagai } \\
\text { souvenir } \\
\text { yang akan } \\
\text { diberikan } \\
\text { pada acara } \\
\text { webinar } \\
\text { Status: } 22 \\
\text { Juli } 2021 \text { - } \\
\text { menunggu } \\
\text { persetujuan }\end{array}$ & $\begin{array}{l}\text { Sistem } \\
\text { akan } \\
\text { menampilk } \\
\text { an } \\
\text { halaman } \\
\text { menu } \\
\text { permintaa } \\
\text { n barang } \\
\text { dan } \\
\text { muncul } \\
\text { alert } \\
\text { permintaa } \\
\text { n barang } \\
\text { berhasil } \\
\text { tersimpan } \\
\text { dan } \\
\text { terkirim }\end{array}$ & $\begin{array}{l}\text { Sesu } \\
\text { ai } \\
\text { hara } \\
\text { pan }\end{array}$ & $\begin{array}{l}\text { Va } \\
\text { lid }\end{array}$ \\
\hline
\end{tabular}

Sumber: Hasil Penelitian (2021)

Tabel 3.

Hasil pengujian black box testing form Input persetujuan barang

\begin{tabular}{|c|c|c|c|c|c|}
\hline $\begin{array}{l}\mathbf{N} \\
\mathbf{0}\end{array}$ & $\begin{array}{c}\text { Skena } \\
\text { rio } \\
\text { Penga } \\
\text { juan }\end{array}$ & Test Case & $\begin{array}{c}\text { Hasil } \\
\text { Yang } \\
\text { Diharap } \\
\text { kan }\end{array}$ & $\begin{array}{c}\text { Hasil } \\
\text { Pengu } \\
\text { jian }\end{array}$ & $\begin{array}{c}\text { Ke } \\
\text { si } \\
\text { m } \\
\text { pu } \\
\text { la } \\
\text { n }\end{array}$ \\
\hline 1 & $\begin{array}{l}\text { Mengo } \\
\text { songka } \\
\text { n salah } \\
\text { satu } \\
\text { form, } \\
\text { kemud } \\
\text { ian } \\
\text { klik } \\
\text { tombol } \\
\text { simpa } \\
\text { n }\end{array}$ & $\begin{array}{l}\text { Nama } \\
\text { Barang: mug } \\
\text { Jumlah } \\
\text { barang: } 20 \\
\text { Tanggal } \\
\text { Permintaan: } \\
\text { 22 Juli } 2021 \\
\text { Pesan } \\
\text { Permintaan: } \\
\text { sebagai } \\
\text { souvenir } \\
\text { yang akan } \\
\text { diberikan } \\
\text { pada acara } \\
\text { webinar } \\
\text { Status: } \\
\text { (kosong) } \\
\text { Tanggal } \\
\text { Persetujuan: } \\
\text { (kosong) } \\
\text { Catatan } \\
\text { persetujuan: } \\
\text { (kosong) } \\
\end{array}$ & $\begin{array}{l}\text { Sistem } \\
\text { akan } \\
\text { menolak } \\
\text { dan } \\
\text { menamp } \\
\text { ilkan } \\
\text { form } \\
\text { input } \\
\text { perminta } \\
\text { an } \\
\text { barang } \\
\text { belum } \\
\text { lengkap, } \\
\text { silakan } \\
\text { input } \\
\text { kembali }\end{array}$ & $\begin{array}{l}\text { Sesuai } \\
\text { harapa } \\
n\end{array}$ & $\begin{array}{l}\text { Va } \\
\text { lid }\end{array}$ \\
\hline 2 & $\begin{array}{l}\text { Mengi } \\
\text { nputka } \\
\mathrm{n} \\
\text { denga } \\
\mathrm{n} \\
\text { benar } \\
\text { kemud } \\
\text { ian } \\
\text { klik } \\
\text { tombol } \\
\text { simpa }\end{array}$ & $\begin{array}{l}\text { Nama } \\
\text { Barang: mug } \\
\text { Jumlah } \\
\text { barang: } 20 \\
\text { Tanggal } \\
\text { Permintaan: } \\
\text { 22 Juli } 2021 \\
\text { Pesan } \\
\text { Permintaan: } \\
\text { sebagai } \\
\text { souvenir }\end{array}$ & $\begin{array}{l}\text { Sistem } \\
\text { akan } \\
\text { menamp } \\
\text { ilkan } \\
\text { halaman } \\
\text { menu } \\
\text { perminta } \\
\text { an data } \\
\text { barang } \\
\text { barang } \\
\text { dan }\end{array}$ & $\begin{array}{l}\text { Sesuai } \\
\text { harapa } \\
n\end{array}$ & $\begin{array}{l}\text { Va } \\
\text { lid }\end{array}$ \\
\hline
\end{tabular}

\begin{tabular}{|c|c|c|}
\hline $\mathrm{n}$ & $\begin{array}{l}\text { yang akan } \\
\text { diberikan } \\
\text { pada acara } \\
\text { webinar } \\
\text { Status: } \\
\text { disetujui - } \\
\text { 31 Juli 2021 } \\
\text { Tanggal } \\
\text { Persetujuan: } \\
\text { 31 Juli 2021 } \\
\text { Catatan } \\
\text { persetujuan: } \\
\text { silakan } \\
\text { meminta } \\
\text { barang } \\
\text { kepada } \\
\text { administrasi }\end{array}$ & $\begin{array}{l}\text { muncul } \\
\text { alert } \\
\text { persetuj } \\
\text { uan } \\
\text { barang } \\
\text { berhasil } \\
\text { tersimpa } \\
\text { n dan } \\
\text { terkirim }\end{array}$ \\
\hline
\end{tabular}

Sumber: Hasil Penelitian (2021)

5. Support

Jika terjadi kesalahan atau error pada sistem, pengelola sistem harus dapat memperbaiki kesalahan atau error tersebut. Pengelola sistem juga harus memperbaharui perangkat lunak antivirus secara berkala untuk mencegah virus menyerang komputer atau memperlambat sistem.

\section{KESIMPULAN}

Dengan sistem yang dibuat dapat meningkatkan kecepatan karyawan, administrasi dan kepala divisi dalam pengelolaan arsip data barang dan data SDM. Karyawan dapat secara langsung mengubah data diri dan melihat ketersediaan barang. Memudahkan Administrasi dalam melakukan pencarian dan laporan data barang dan data SDM. Kepala divisi dapat secara langsung menerima laporan terbaru data barang dan data SDM. Jika dilakukan dengan sistem cukup melakukan penginputan pada aplikasi yang sudah ada, hal ini dapat menghemat waktu dan mengurangi kesalahan perhitungan data barang.

\section{REFERENSI}

Firman, C. E. (2019). Penentuan Pola Yang Sering Muncul Untuk Penjualan Pupuk Menggunakan Algoritma Fp-Growth. I N F O $\begin{array}{lllllllll}R & M & a & T & I & K & A, & 9(2), & 1 .\end{array}$ https://doi.org/10.36723/juri.v9i2.97

Guide, B. P. (2018). Jajanan Pasar Tradisional, Murah dan tanpa bahan kimia. Retrieved July 31, 2021, from https://bpguide.id/AX1TCIdb

Kanti, S., \& Indrajit, R. E. (2017). Implementasi Data Mining Penjualan Handphone Oppo Store Sdc Tanggerang Dengan Algoritma 
Appriori. Implementasi Data Mining

Penjualan Handphone Oppo Store Sdc

Tanggerang Dengan Algoritma Appriori, (November), 1-2.

Kusbianto PA, D., Ananta, A., \& Nanda, B. (2019). IMPLEMENTASI ANALISA KERANJANG BELANJA GUNA MENENTUKAN PAKET PRODUK DENGAN ALGORITMA FPGROWTH, 1-5. Retrieved from http://jurnalti.polinema.ac.id/index.php/SIA $\mathrm{P} /$ article/view/624/220

Lestari, Y. D. (2017). Penerapan Data Mining Menggunakan Algoritma Fp-Tree Dan FpGrowth Pada Data Transaksi Penjualan Obat, (Snastikom), 60-65. https://doi.org/10.31227/osf.io/t93uv

Nurelasari, E. (2017). Penerapan Algoritma KMeans dan FP-Growth untuk Analisis Keranjang Pasar pada Penjualan Produk Alumunium, 1(2), 179-186.

Prasetyo, A., Musyaffa, N., \& Sastra, R. (2020). Implementasi Data Mining Untuk Analisis Data Penjualan Dengan Menggunakan Algoritma Apriori ( Studi Kasus Dapoerin ' S ), $\operatorname{VIII}(2)$.

Rahman, A. (2021). Pelaku Usaha Kuliner Keluhkan Dampak PPKM Darurat Jawa-Bali. Retrieved July 31, 2021, from https://lomboktvnews.com/pelaku-usahakuliner-keluhkan-dampak-ppkm-daruratjawa-bali/ 